\title{
The Problems and Countermeasures on Construction of Social Work Practice Base: Taking Hubei Minzu University as an Example
}

\author{
Li Huang \\ School of Law \\ Hubei Minzu University \\ Enshi, China \\ phoebe22222@126.com
}

\begin{abstract}
Social work is a very practical major. The construction of practice base which has a key role in the cultivation of social work personnel is an important and necessary part of social work practice teaching. This paper takes Hubei Minzu University as an example analyzing its practices and problems on construction of social work practice base. At last, this paper suggests some countermeasures to strengthen the construction of social work practice base in order to improve the quality of social work education.
\end{abstract}

Keywords-Social work practice base; Practice teaching;laboratory;double type teaching staff.

\section{INTRODUCTION}

The research on construction of social work practice base ${ }^{1}$ has a strong theoretical and practical significance, mainly reflected in three aspects. First, from the importance of practice base construction, practice base is an important place to cultivate students' innovative spirit and practical abilities. It is an important condition and guarantees to realize the goal of talent cultivation in universities.[1] According to the documents promulgated by Chinese Ministry of Education, such as "On further strengthening the undergraduate teaching work in colleges and universities" (2005), " A number of views on further deepening of the reform of teaching quality " (2007) and "National long-term education reform and development plan (2010-2020)" , practical teaching in universities is required to attach great importance to. Obviously, the practice base construction has become the important problem in the development of higher education in our country. It is the key factor that affects the quality of personnel training in Colleges and universities.

Social work is a very practical major. "Social work practice is an organic part of the whole social work education. It has an important position in the professional training, and is an important way to achieve professional quality".[2] Therefore social work practice is a compulsory phase in social work education required by Ministry of Education. However, for a

\footnotetext{
${ }^{1}$ This paper is a stage achievement of the research project "Research and practice on the construction of social work practice base in the universities for nationalities" (13063) sponsored by the State Ethnic Affairs Commission of the People's Republic of China.
}

long time, the social work practice has been a weakness of the social work education in our country. Social work practice is a kind of "clinical" practice.[3] It must rely on the construction of practice base, so that students can use social work professional knowledge, skills and values in the actual work situation and to achieve professional self growth. Therefore the construction of practice base which has a key role in the cultivation of social work personnel is an important and necessary part of social work practice teaching. But in the social work education situation in China, the practice teaching has become the main bottleneck to restrict the quality of social work education.[4] To strengthen the research and practice of social work practice base construction is helpful to break through the bottleneck of domestic social work education, and it has important significance to the localization of social work.

Secondly, from the characteristics and the status quo of the social work education in university for nationalities, the construction of social work started late, but developed rapidly. University for nationalities is a special form of higher education in our country. At present, 10 universities for nationalities among 15 colleges and universities for nationalities set up social work major (66.7\%). These universities for nationalities have made important contributions to the training of professional social work talents, but also face many difficulties and challenges, especially in the construction of social work practice base. Because the development of social work practice in minority ethnic region is limited, there is a lack of suitable training institutions for social work practice. The contact between the school and the practice is not closely related. The management of social work practice base is not standardized. The practice content is not reflected in the professional features and the effect of the practice base construction is difficult to evaluate and so on.[5] How to break through their own development and regional restrictions, to do a good job of social work practice base construction, management, operation and evaluation of work and other issues need to be studied and solved.

Finally, from the social needs of social work professionals, the construction of social work practice base also has important significations. The $16^{\text {th }}$ plenary session of the Party's $6^{\text {th }}$ plenary session pointed out that "creating a reasonable structure, qualified social work personnel is an urgent need to build a 
socialist harmonious society". The report of $17^{\text {th }}$ and $18^{\text {th }}$ National Congress of the CPC further defined the position and function of social workers as an important factor of social construction. Sense the focus and difficulty of current social construction and social management innovation are concentrated in minority ethnic regions; the demand of social worker in minority ethnic regions is huge. Most universities for nationalities in China are located in minority ethnic regions which has obvious geographical and resource advantages in the cultivation of minority nationality talents and development of the areas. The research of this paper will be helpful for the integration of construction of social work practice base into the practice of social work in minority ethic regions, as well as to strengthen the social service ability of universities for nationalities, and promote the social construction and social management innovation in minority ethnic regions.

\section{StATUS ANAlYSIS ON HUBEI MINZU UNIVERSITY' S PRACTICES ON CONSTRUCTION OF SOCIAL WORK PRACTICE BASE}

Hubei Minzu University (short for HMU) started social work education in 2007. Though 8 years, there are over 20 teachers and 260 students now. HMU has always paid a lot of attention to the construction of social work practice base to improve the quality of professional social work personnel training.

\section{A. Build social work laboratories}

In 2009 HMU invested more than 0.4 million to build social work laboratories such as Case Work Laboratory, Statistical Analysis Laboratory, Network Classroom and Activities Multimedia Classrooms with a total area of nearly 200 square meters and 60 computers. There are also Sand tray therapy tools, group social work tools, psychological assessment software and statistical analysis software. Since establishment, social work laboratories have been providing support for many social work courses (such as Case Work, Group Work, Psychotherapy, etc) and students' self-learning. On this basis, the comprehensive laboratory of social governance has received 0.3 million of funds to be retrofitted in order to provide more favorable conditions for practice teaching after the completion.

\section{B. Construct various social work practice bases outside the campus}

Considering the difficulties of constructing social work practice base in minority ethnic regions, teachers of HMU step out of the school gate and seek parental practice base all of the country. Though years of effort, it has built up over 20 social practice bases including relative government departments, social organizations and professional social work organizations in Hubei, Guangdong and Fujian provinces. For examples, the practice bases are Enshi Civil Affairs Bureau, WuyangBa Street office, Enshi special education schools, Enshi Jinziba middle school, Guangzhou Datong social work service center, Shenzhen Beidou social work service center, Jingjiang Zhihe social work service center and so on. After completion, HMU explores many ways of using these practice bases to benefit teaching such as organizing social work practice and course practice inside these practice bases. Each year, many students are arranged to work in these practice bases to enhance their professional abilities. Over the years, students adhered to carry out adolescent social work practice in Enshi Jinziba middle school, providing psychological and spiritual support for students. Students also organized colorful social practice activities combining with voluntary service and professional practice. Some activities had a greater social impact and was reported by the local TV station.

\section{Set up a progressive system of practice teaching}

Corresponding to the professional level of students in different grades, HMU designed and set up a progressive system including "voluntary service - social investigation course practice - graduate internship" of practice teaching to help students in different grades to cultivate professional cognitive, develop professional awareness, train professional skills, and establish professional confidence. For the freshman and sophomore, volunteer services and social investigation during vacations are required to exercise students' understanding of society and research capabilities. And for students of grade 3, the main forms of practice is practice during curriculum teaching( named "course practice" ) such as Case Work, Group Work, Community Work, Psychological Counseling, Painting and Sand tray Therapy to guide students to integrate social work theories and skills into practice. At last for students of grade 4,8 weeks of graduate internship is required to improve students' comprehensive professional abilities. During the whole teaching period, the time of practice teaching accounted for $18.5 \%$ of total class hour. This system of practice teaching highlighted the school mission as "application technology university". After 3 years of practice, through the feedback of students and teachers, the students are satisfied with the course setting and the teaching effect of social work major garnered strong reviews.

\section{Existing problems}

The construction of social work practice base has gained some achievement but also has a lot of problems. At first, because of the expansion of enrollment, the existing practice teaching resources are very tight. In the last three years, the number of students increased by nearly double greatly exceeds the laboratory load so that some practical activities can not be carried out smoothly. For example, the existing activity classroom and statistical analysis laboratory can only accommodate 60 people at the same time, so that some students have to sit in the aisle during class.

Secondly, the facilities are outdated and failed to meet the special needs of professional teaching and the development of the major. For example, because of lacks of real-time video and monitoring equipments, teachers can not observe and record during students' practice process, and can not feedback in time.

Finally, the function of the practice base is limited and greatly restricts the education quality of social work. At present, the existing laboratories and practice bases can only deal with the basic needs of teaching, the function such as external communication and social service are not played out. 


\section{COUNTERMEASURES}

Although the construction of social work practice base in Hubei Minzu University has achieved some achievements, there are a lot of problems and difficulties affecting the further development of social work education in HMU. In order to solve these problems and to provide reference for other schools, we suggest some countermeasures as followed.

A. Strengthen the planning and building of high-level social work practice base

The content of social work major is divided into 3 parts, such as social work theories, skills and values. The teaching of social work professional skills and methods is different from the knowledge teaching. It is difficult to achieve good results only with teachers' teaching activities. It is necessary to lead students to experience and improve in practice. The social work practice base is beneficial to observe and record the students' practicing process, and it has an irreplaceable important role in social work. Therefore, many universities around the world have paid much attention to the construction of social work practice bases. To strengthen the further development of existing practice base, we should think though about the goal emphasizing social work values, theories and skills as a whole and make a long-term plan to meet the development of social work major. Social work practice bases should be scientific and effective in order to enhance students' professional abilities and improve the quality of social work education.

\section{B. Reform and upgrade the existing practice base resources from time to time}

To meet the development of the society, the discipline and the students, the reforming and upgrading of the existing practice base resources is necessary. With reference to the standards made by Chinese social worker education Association, the software and hardware conditions of social work practice base should be upgraded from time to time to provide a good foundation for social work teaching.

For many schools, the difficulty of resource upgrading lies in the shortage of funds. So social work practice base outside the campus is a good choose.[6] By building social work practice base outside the campus, we can share resources with other organizations and save construction cost. HMU has made a lot of efforts seeking practice resources around the country and gained some achievements. HMU's practices tell us that as long as we take the initiative to go out, the practice resources are very rich.

\section{Explore better ways to strengthen ties between practice bases with the school}

The completion of the social work practice base is not the end of work. The only way to really stimulate the function of practice base is to strengthen ties between the practices bases and the school and integrate the practice process into teaching. [7] As showed earlier, students of different grades have different professional levels and motivations, so the goals and contents of practice should be relevant, combining teacher's supervision and students' independent learning together. And also different practice bases have different missions and professional levels, so that the using of these practice bases should be based on its own characters in order to train different aspects of abilities. So a flexible system of practice teaching is needed to support the construction of social work practice base. In fact, the ways of social work practice are varied including social investigation, course practice, internship and volunteer service and so on. So the system of social work practice teaching could combine different ways of practice to meet different needs of students and make full use of practice base.

\section{Establish a double type teaching staff}

The quality of teaching staff is the key to the quality of education. In order to improve the social work education, double type teaching staffs including teachers from universities who has strong theoretical understanding of social work as well as social workers from practice bases whose specialties is in the application of social skills. Under the supervisions of both type of teachers, students' social knowledge and skills could be enhanced significantly. And teachers of universities should develop their own theory and practice abilities, especially the ability to link theory with practice. So students can learn a lot from this type of teachers by observing teachers' demonstration and learn how to apply theory to reality.

\section{E. Expand multiple functions of practice base}

One of the important functions of university is to serve local development. So the construction of social work practice base is not only helpful for social work education in university but also good for the development of the practice base itself. Therefore we should expand multiple functions of practice base by conducting researches to solve the problems and training the staff of practice base to achieve a win-win situation for both social work practice base and the university. [8] From this point of view, the construction of social work practice base is not only an issue of social work education but also an important measure to promote the development of social work practice in China.

\section{CONLUSION}

The construction of social work practice base is an important part in the social work education. This paper taking Hubei Minzu University as an example to analyze the methods of constructing social work practice base inside and outside the campus can provide reference for other schools. Especially, the problems and difficulties mentioned above are not for Hubei Minzu University, but a common phenomenon in universities of nationalities. Therefore, there are a lot of thinking and practice needed to be done to strengthen the construction of social work practice base and to improve the quality of social work education.

\section{REFERENCES}

[1] Huali Liu \& Lihong Hu. "On the importance of promoting the construction of practice base. "Social Work(Academic Edition ), 2004.9.

[2] Sinbin Wang. "Introduction to social work (Second Edition). "Beijing: Higher Education Press,2006.p256.

[3] Bonian Shi \& Xin Hou. "Social work practice." Beijing: Social Science Literature Press,2003.p15. 
[4] Yong Liu. "Exploration on the construction of practice base of social work major. "Journal of Guangdong University of Technology (social science edition), 2006.12.

[5] Rong Xiang. "A re-exploration of the educational mode of social work practice in China." Research on Higher Education in Yunnan,2000.2.

[6] Yuanhui Li. "Strengthen the Construction of Practice Base Outside the College and Improve the Quality of Practice Teaching.'Research and Exploration on Laboratory, 2009.6.
[7] Liang Ma. "Research on the construction of "practice-teaching-research' social work practice base." Journal of Zhejiang Gongshang University,2011.4.

[8] Yihong Zhan \& Shun Hou. "Strengthen the construction of practice base and expand the employment channels of university graduates. "Education Research,2006.9. 